\section{Resistance to Gray Leaf Spot in Capsicum Peppers}

\author{
H.J. Cho' ${ }^{1}$ B.S. Kim ${ }^{2}$, and H.S. Hwang ${ }^{1}$ \\ Department of Horticulture, Kyungpook National University, Taegu 702-701, \\ Korea
}

Additional index words. Capsicum annuum, Stemphylium solani, Stemphylium lycopersici, pathology, breeding

Abstract. Of 467 accessions of Capsicum pepper (Capsicum annuum L.) tested for resistance to gray leaf spot, KC321, KC220, KC208, KC47 (PI244670), KC43 (PI244670), KC380, and KC319 were highly resistant to both Stemphylium solani and S. lycopersici, the causal agents of gray leaf spot.

Gray leaf spot, caused by Stemphylium solani Weber, was first reported on tomatoes by Weber (1930) in Florida. Hannon and Weber (1955) found that another closely related species of Stemphylium also caused gray leaf spot on tomatoes (Lycopersicon esculentum Mill.), symptoms of which were indistinguishable from those caused by $S$. solani. They named this new species $S$. floridanum; its current name is Stemphylium lycopersici (Enjoji) Yamamoto (Ellis and Gibson, 1975). Both $S$. solani and $S$. lycopersici are also pathogenic on pepper (Hannon and Weber, 1955; Weber, 1930).

Gray leaf spot on pepper caused by $S$. solani was first observed in a natural field condition in Louisiana by Sinclair et al. (1958) and later in Florida by Blazquez (1969), but its occurrence on pepper caused by S. lycopersici has not been reported previously.

We have observed severe leaf spot and defoliation on pepper plants caused by gray leaf spot in Korea since 1994. The disease was more prevalent on plants growing in relatively cool mountainous terrain, such as Subi-Myun, Youngyang in Kyungpook province. Two different species of Stemphylium were isolated from the diseased leaves, depending on the specimen collected. The causal fungi were identified as Stemphylium solani and $S$. lycopersici, respectively (Cho, 1997).

Studies on resistance to the disease have been conducted since 1996 in a wide range of genetic resources. Good levels of resistance have been observed and the results are reported here.

\footnotetext{
Received for publication 22 Nov. 1999. Accepted for publication 6 Nov. 2000. This research was funded by the Ministry of Agriculture, Forestry, and Fisheries, Special Grants Research Program (MAFSGRP) in Korea. The cost of publishing this paper was defrayed in part by the payment of page charges. Under postal regulations, this paper therefore must be hereby marked advertisement solely to indicate this fact.

${ }^{1}$ Graduate student.

${ }^{2}$ Professor. To whom reprint requests should be addressed. E-mail address: bskim@knu.ac.kr
}

in humid conditions generated by wetting the bottom carpet or soil of the nursery bed with water and covering it with a plastic film.

Disease was scored 5 to $7 \mathrm{~d}$ after inoculation using an arbitrary scale based on the number of spots and discoloration on the most diseased leaves on a plant: $1=$ no spots found; $2=$ one to three spots; $3=$ four to six spots; 4 $=7$ or more spots but no discoloration; and 5 $=7$ or more spots with discoloration or defoliation.

Expt. 2. Confirmation evaluation for resistance to both S. solani and S. lycopersici. A total of 23 accessions, consisting of 20 lines selected as potentially resistant in preliminary mass screening and three susceptible checks (Kumtap, Subi and Chilsung), were sown in Barokur $^{\circledR}$ mix in 128-cell trays in the greenhouse. The germinated seedlings were transferred to 32-cell trays filled with Barokur ${ }^{\circledR}$ mix 1 month after seeding. Two sets of a maximum of 10 plants for each accession were grown, one set for inoculation with $S$. solani and the other for inoculation with $S$. lycopersici.

Plants of each set of accessions were inoculated with spore suspensions of isolates of either S. solani or S. lycopersici collected from Ipseok, Andong, Kyungpook province. For sporulation, both species of Stemphylium were seeded on $\mathrm{V}^{\circledR}{ }^{\circledast}$ juice agar plates with three to four mycelial pieces in each plate and cultured at 20 to $25^{\circ} \mathrm{C}$ and a 12 -h photoperiod provided by fluorescent lights. Plastic petri dishes were used instead of the glass ones made in Korea. Both $S$. solani and $S$. lycopersici sporulated abundantly. Spores were collected from 3-dold cultures on the plates and spore suspensions were prepared as in Expt. 1.

Pepper seedlings were inoculated and incubated as in Expt. 1. Disease was scored $16 \mathrm{~d}$ after inoculation based on two scales, disease index as in the preliminary mass screening, and the average number of spots formed on the three most diseased leaves of each plant, counted with a mechanical counter. The experiment was conducted on seedlings grown in trays and 6 to 10 plants were tested per accession. Therefore, a completely randomized design was used, considering the individual plants in each line as replications. The SAS GLM and MEANS procedure was used for statistical analysis.

\section{Results and Discussion}

Expt. 1. Preliminary mass screening. A total of 101 accessions were tested in the first set, of which eight showed mean disease indices $<2.0$ (Table 1 ). No spots were found on KC47 'PI244670', KC174 'Early Jalapeno', or KC380 'Habuksung'. Accessions showing resistance in the first set were evaluated in an outdoor nursery in the second set. However, bacterial spot and Phytophthora blight interfered with disease readings and reduced the number of usable plants. The six least-diseased accessions of the 206 tested are listed in Table 1. Two of the best three accessions were among those selected in the first set. In the third set, 13 accessions of the 171 tested showed mean disease indices $<2.0$, with $\mathrm{KC} 380, \mathrm{KC} 47$ 
and $\mathrm{KC} 319$, which were included as resistant controls, ranking highest among resistant lines (Table 1).

Expt. 2. Confirmation evaluation for resistance to both $S$. solani and S. lycopersici. Twenty accessions selected in preliminary evaluations and three susceptible controls were tested again for resistance to both $S$. solani and S. lycopersici. KC320, KC220, KC208, KC47 (PI244670), KC43 (PI241670), KC380, and KC319 were highly resistant to both $S$. solani and $S$. lycopersici (Table 2) as expected, based on results of the preliminary tests. Numerous spots developed on the susceptible controls such as 'Subi', 'Chilsung' and 'Kumtap', causing discoloration and defoliation. Some other accessions were also less affected than the susceptible controls. The resistant accessions, which were initially selected only for resistance to S. lycopersici, showed resistance to both $S$. solani and S. lycopersici. The phenotypic correlations between both the mean disease indices and the mean numbers of spots formed on the three most diseased leaves for the two Stemphylium species $(0.92$ and 0.87 , respectively) were highly significant. The coefficients of variation for disease index and mean number of spots on a leaf were $21 \%$ and $52 \%$, respectively, for inoculation with S. solani and $29 \%$ and $70 \%$, respectively, for inoculation with $S$. lycopersici. Thus, disease index was the better indicator of resistance. Counting the number of spots on the leaves was timeconsuming and tedious.

PI244670 and PI241670 were resistant to Stemphylium and have been reported to possess quantitative resistance to bacterial spot (Cook and Stall, 1963; Kim, 1988; Sowell, 1960). KC14 (PI201234) has resistance to Phytophthorablight(Kim, 1986, 1988; Kimble and Grogan, 1960) and was also moderately resistant to gray leaf spot. All of the resistant lines and the other genotypes used in this study are maintained by the second author and available to interested parties.

Although Weber (1930) reported that $S$. solani sporulated well on potato dextrose agar, we had difficulty in inducing sporulation. However, S. lycopersici sporulated abundantly on mycelial blocks when incubated on water agar with $\mathrm{CaCO}_{3}$ under cool, dark conditions as reported for Alternaria species (Sahin and Shepard, 1979). This was the reason why we used $S$. lycopersici in the preliminary evaluations, although $S$. solani is the dominant species in Korea (Cho, 1997). Later, we found that the glass lids of domestically produced petri dishes inhibited sporulation, possibly by blocking transmission of ultraviolet light. Abundant sporulation was obtained when plastic petri dishes were used. We also found that both species were sporulating well on $\mathrm{V}^{\circledR}$ juice agar in Pyrex ${ }^{\circledR}$ glass petri dishes

Gray leaf spot is an important disease in pepper fields located in mountainous terrain in Korea, and the resistant lines selected will be used in breeding for resistance.
Table 1. Resistance to Stemphylium lycopersici in the top class accessions and in the susceptible control 'Kumtap' in the three sets of plantings.

\begin{tabular}{|c|c|c|c|c|c|c|c|}
\hline \multirow[b]{2}{*}{ KC no. } & \multirow[b]{2}{*}{ Cultivar } & \multicolumn{2}{|c|}{ First planting } & \multicolumn{2}{|c|}{ Second planting } & \multicolumn{2}{|c|}{ Third planting } \\
\hline & & $\begin{array}{l}\text { No. } \\
\text { plants } \\
\text { tested }\end{array}$ & $\begin{array}{c}\text { Mean } \\
\text { disease } \\
\text { index }^{z}\end{array}$ & $\begin{array}{c}\text { No. } \\
\text { plants } \\
\text { tested }\end{array}$ & $\begin{array}{c}\text { Mean } \\
\text { disease } \\
\text { index }^{2}\end{array}$ & $\begin{array}{l}\text { No. } \\
\text { plants } \\
\text { tested }\end{array}$ & $\begin{array}{c}\text { Mean } \\
\text { disease } \\
\text { index }^{z}\end{array}$ \\
\hline 47 & PI244670 & 10 & $1.0 \mathrm{a}^{\mathrm{y}}$ & --- & --- & 12 & $1.1 \mathrm{a}$ \\
\hline 174 & Early Jalapeno & 10 & $1.0 \mathrm{a}$ & 3 & $1.7 \mathrm{a}$ & --- & --- \\
\hline 380 & Habuksung ${ }^{\mathrm{x}}$ & 10 & $1.0 \mathrm{a}$ & --- & --- & 12 & $1.1 \mathrm{a}$ \\
\hline 319 & Unknown $^{\mathrm{x}}$ & 10 & $1.2 \mathrm{a}$ & 8 & $1.1 \mathrm{a}$ & 12 & $1.2 \mathrm{ab}$ \\
\hline 43 & PI241670 & --- & --- & 8 & $1.3 \mathrm{a}$ & --- & --- \\
\hline 158 & Red chili & --- & --- & --- & --- & 12 & $1.3 \mathrm{a}-\mathrm{c}$ \\
\hline 320 & Unknown & --- & --- & --- & --- & 12 & $1.4 \mathrm{a}-\mathrm{d}$ \\
\hline 318 & Albaregia & --- & --- & --- & --- & 12 & $1.5 \mathrm{a}-\mathrm{d}$ \\
\hline 157 & Papri Sweet & --- & --- & --- & --- & 6 & $1.5 \mathrm{a}-\mathrm{d}$ \\
\hline 14 & PI201234 & 11 & $1.6 \mathrm{~b}$ & --- & --- & -- & --- \\
\hline 220 & Beopjeon & 11 & $1.6 \mathrm{~b}$ & --- & --- & --- & --- \\
\hline 40 & PI241641 & --- & --- & --- & --- & 5 & $1.6 \mathrm{a}-\mathrm{d}$ \\
\hline 314 & Hungary & 11 & $1.7 \mathrm{~b}$ & --- & --- & --- & --- \\
\hline 208 & Jinan & --- & --- & 8 & $1.7 \mathrm{a}$ & --- & --- \\
\hline 304 & Tam Mild Jalapeno & --- & --- & --- & --- & 12 & $1.7 \mathrm{a}-\mathrm{d}$ \\
\hline 312 & Kecskeszarv & 11 & $1.8 \mathrm{~b}$ & --- & --- & --- & --- \\
\hline 52 & PI257047 & --- & --- & 7 & $1.8 \mathrm{a}$ & --- & --- \\
\hline 6 & PI164677 & --- & --- & 6 & $1.8 \mathrm{a}$ & --- & --- \\
\hline 390 & Dochigi-Sandaka & --- & --- & --- & --- & 12 & $1.8 \mathrm{~b}-\mathrm{d}$ \\
\hline 195 & Seodong & --- & --- & --- & --- & 12 & $1.8 \mathrm{~b}-\mathrm{d}$ \\
\hline 322 & Navator $F_{1}$ & --- & --- & --- & --- & 11 & $1.8 \mathrm{~cd}$ \\
\hline 305 & Tam Mild Chile & --- & --- & --- & --- & 8 & $2.0 \mathrm{~d}$ \\
\hline$F_{1}$ hybrid & Kumtap & 11 & $4.9 \mathrm{c}$ & 4 & $4.0 \mathrm{~b}$ & 12 & $4.7 \mathrm{e}$ \\
\hline
\end{tabular}

${ }^{\mathrm{z}} 1=$ no spots; $2=1-3$ spots on a leaf; $3=4-6$ spots; $4=7$ or more spots developed on a leaf but no yellowing; $5=7$ or more spots per leaf with yellowing.

${ }^{y}$ Mean separation within columns by Duncan's multiple range test, $P \leq 0.05$.

${ }^{x}$ Resistant controls.

Table 2. Disease ratings for selected lines of pepper after inoculation with Stemphylium solani and $S$. lycopersici

\begin{tabular}{|c|c|c|c|c|c|c|}
\hline \multirow[b]{2}{*}{ KC no. } & \multirow[b]{2}{*}{ Cultivar } & \multirow[b]{2}{*}{$\begin{array}{l}\text { No. plants } \\
\text { tested }\end{array}$} & \multicolumn{2}{|c|}{ S. solani } & \multicolumn{2}{|c|}{ S. lycopersici } \\
\hline & & & $\begin{array}{l}\text { No. spots } \\
\text { per leaf }\end{array}$ & $\begin{array}{l}\text { Mean } \\
\text { disease } \\
\text { index }^{y}\end{array}$ & $\begin{array}{l}\text { No. spots } \\
\text { per leaf }^{2}\end{array}$ & $\begin{array}{c}\text { Mean } \\
\text { disease } \\
\text { index }^{y}\end{array}$ \\
\hline 320 & Unknown & 10 & $0.2 \mathrm{a}^{\mathrm{x}}$ & $1.4 \mathrm{a}$ & $0.0 \mathrm{a}$ & $\frac{1.0 \mathrm{a}}{\mathrm{s}}$ \\
\hline 220 & Beopjeon & 10 & $0.4 \mathrm{a}$ & $1.4 \mathrm{a}$ & $0.0 \mathrm{a}$ & $1.0 \mathrm{a}$ \\
\hline 208 & Jinancho & 8 & $1.4 \mathrm{a}$ & $1.4 \mathrm{a}$ & $1.0 \mathrm{a}$ & $0.0 \mathrm{a}$ \\
\hline 47 & PI244670w & 10 & $1.9 \mathrm{a}$ & $2.5 \mathrm{~b}$ & $1.2 \mathrm{a}$ & $0.3 \mathrm{a}$ \\
\hline 43 & PI241670 & 7 & $2.4 \mathrm{a}$ & $2.1 \mathrm{ab}$ & $1.6 \mathrm{ab}$ & $0.7 \mathrm{a}$ \\
\hline 380 & Habuksung ${ }^{\mathrm{w}}$ & 10 & $2.4 \mathrm{a}$ & $1.6 \mathrm{a}$ & $1.1 \mathrm{a}$ & $0.0 \mathrm{a}$ \\
\hline 319 & Unknown ${ }^{\mathrm{w}}$ & 10 & $7.4 \mathrm{ab}$ & $2.0 \mathrm{ab}$ & $2.2 \mathrm{bc}$ & $3.0 \mathrm{ab}$ \\
\hline 390 & Dochigi-Sandaka & 10 & $15.8 \mathrm{a}-\mathrm{c}$ & $3.9 \mathrm{de}$ & $3.3 \mathrm{~d}-\mathrm{f}$ & $20.3 \mathrm{~cd}$ \\
\hline 174 & Early Jalapeno & 10 & $16.8 \mathrm{a}-\mathrm{c}$ & $3.6 \mathrm{~cd}$ & $2.5 \mathrm{~cd}$ & $2.7 \mathrm{ab}$ \\
\hline 195 & Seodong & 10 & $22.7 \mathrm{bc}$ & $3.2 \mathrm{c}$ & $2.6 \mathrm{~cd}$ & $16.5 \mathrm{~b}-\mathrm{d}$ \\
\hline 158 & Red chili & 10 & $24.3 \mathrm{~b}-\mathrm{d}$ & $4.1 \mathrm{de}$ & $3.3 \mathrm{~d}-\mathrm{f}$ & $8.1 \mathrm{a}-\mathrm{c}$ \\
\hline 326 & Kesckeszarv & 10 & $30.0 \mathrm{c}-\mathrm{e}$ & $4.1 \mathrm{de}$ & $2.9 \mathrm{e}-\mathrm{g}$ & $18.5 \mathrm{~cd}$ \\
\hline 305 & Tam Mild chile & 6 & $31.8 \mathrm{c}-\mathrm{e}$ & $4.0 \mathrm{de}$ & $3.6 \mathrm{e}-\mathrm{g}$ & $27.3 \mathrm{~d}$ \\
\hline 14 & PI201234 & 10 & $31.9 \mathrm{c}-\mathrm{e}$ & $4.0 \mathrm{de}$ & $3.9 \mathrm{fg}$ & $21.2 \mathrm{~cd}$ \\
\hline 304 & Tam Mild Jalapeno & 9 & $41.0 \mathrm{~d}-\mathrm{f}$ & $4.0 \mathrm{de}$ & $3.3 \mathrm{~d}-\mathrm{f}$ & $7.1 \mathrm{a}-\mathrm{c}$ \\
\hline 40 & PI241641 & 10 & $41.4 \mathrm{~d}-\mathrm{f}$ & $4.0 \mathrm{de}$ & $3.9 \mathrm{fg}$ & $27.9 \mathrm{~d}$ \\
\hline 6 & PI164677 & 10 & 43.4 ef & $4.0 \mathrm{de}$ & $3.3 \mathrm{ab}$ & $2.8 \mathrm{c}-\mathrm{e}$ \\
\hline 322 & Navator $F_{1}$ & 8 & $44.7 \mathrm{ef}$ & $4.3 \mathrm{de}$ & $55.7 \mathrm{e}$ & $4.3 \mathrm{~g}$ \\
\hline 312 & Keckeszarv & 10 & $54.8 \mathrm{fg}$ & $4.2 \mathrm{de}$ & $44.7 \mathrm{e}$ & $4.1 \mathrm{fg}$ \\
\hline 157 & Papri Sweet & 10 & $62.6 \mathrm{~g}$ & $4.1 \mathrm{de}$ & $28.4 \mathrm{~d}$ & $4.0 \mathrm{fg}$ \\
\hline 202 & Subi & 10 & $86.1 \mathrm{~h}$ & $4.6 \mathrm{e}$ & $77.6 \mathrm{f}$ & $4.5 \mathrm{~g}$ \\
\hline$F_{1}$ hybrid & Kumtap & 10 & $96.1 \mathrm{hi}$ & $4.3 \mathrm{de}$ & $56.8 \mathrm{e}$ & $4.5 \mathrm{~g}$ \\
\hline 201 & Chilsung & 10 & $107.3 \mathrm{i}$ & $4.6 \mathrm{e}$ & $48.4 \mathrm{e}$ & $4.3 \mathrm{~g}$ \\
\hline
\end{tabular}

${ }^{2}$ Mean number of spots formed on the three most diseased leaves.

'Disease index of the most diseased leaf on a plant: $1=$ no spots; $2=1-3$ spots; $3=4-6$ spots; $4=7$ or more spots formed but no yellowing; $5=7$ or more spots on a leaf with discoloration and defoliation.

${ }^{x}$ Mean separation within columns by Duncan's multiple range test, $P \leq 0.05$.

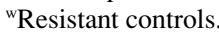




\section{Literature Cited}

Blazquez, C.H. 1969. Occurrence of gray leaf spot on peppers in Florida. Plant Dis. Rptr. 53:756.

Cho, H.J. 1997. Identification of Stemphylium spp. causing gray leaf spot of pepper and search for resistance to gray leaf spot. MS Thesis, Kyungpook Natl. Univ., Taegu, Korea.

Cook, A.A. and R.E. Stall. 1963. Inheritance of resistance in pepper to bacterial spot. Phytopathology 53:1060-1062.

Ellis, M.B. and I.A.S. Gibson. 1975. Stemphylium lycopersici.CMI descriptions of pathogenic fungi and bacteria No. 471. Commonwealth Mycol. Inst., Ferry Lane, Kew, Surrey, England.

Hannon, C.I. and G.F. Weber. 1955. A leaf spot of tomato caused by Stemphylium floridanum $\mathrm{sp}$. nov. Phytopathology 45:11-16.

Kim, B.S. 1986. Resistance to Phytophthora root rot in introduced peppers (Capsicum spp.). J. Korean Soc. Hort. Sci. 27:11-14.

Kim, B.S. 1988. Characteristics of bacterial spotresistant lines and Phytophthora blight-resistant lines of Capsicum pepper. J. Korean Soc. Hort. Sci. 29:247-252.

Kimble, K.A. and R.G. Grogan 1960. Resistance to
Phytophthora root rot in pepper. Plant Dis. Rptr. 44:872-873.

Sahin, E.A. and J.F. Shepard. 1979. An efficient technique for inducing profuse sporulation of Alternaria species. Phytopathology 69:618-620.

Sinclair, J.B., N.L. Horn, and E.C. Time. 1958. Unusual occurrence of certain diseases in Louisiana. Plant Dis. Rptr. 42:984-985.

Sowell, G. Jr. 1960. Bacterial spot resistance of introduced peppers. Plant Dis. Rptr. 44:587-590.

Weber, G.F. 1930. Gray leaf spot of tomato caused by Stemphylium solani $\mathrm{sp}$. nov. Phytopathology 20:513-518. 